\title{
CONFLICT RESOLUTION IN SYAIR SULTAN MAULANA
}

\section{(Penyelesaian Konflik dalam Syair Sultan Maulana)}

\author{
Wan Roshazli Wan Razali* \\ amsya_gurlz@yahoo.com \\ Sakinah Abu Bakar \\ sakinah57@yahoo.com \\ Centre for Distance Education \\ Universiti Sains Malaysia.
}

Published online: 9 June 2020

To Cite: Wan Roshazli Wan Razali and Sakinah Abu Bakar. (2020). Conflict Resolution in Syair Sultan Maulana. Malay Literature, 33(1), 1-20.

This article discusses the conflicts and resolutions in Syair Sultan Maulana. The researcher aims to prove that works written in the past do not come out of nowhere but are the products of the author's wisdom to deliver a meaningful message through the use of symbols. In the context of this text, the author has applied several ways or methods of conflict resolution used by the local people in the past to ensure continued harmony in their fatherland. Therefore, this article will uses the conflict resolution approach introduced by Abdullah Hassan and Ainon Mohd. This approach lists several methods for resolution, such as cooperation, negotiation, domination, avoidance, integrity, obligation, and compromise. Malay literary works, especially historical ones, usually also deal with the lives of the people at the time. In traditional Malay literary works, many issues are discussed for the benefit of future generations. The most interesting aspects of these classical texts are the conflicts, problems, and disputes occurring in the community at the time, whether they are among the royalty, nobility or ordinary folk.

Keywords: Conflict, resolution, syair, historical literature, harmony

(C) Dewan Bahasa dan Pustaka. 2020. This work is licensed under the term of the Creative Commons Attribution (CC BY) (http://creative commons.org/licenses/by/4.0/) 


\begin{abstract}
Abstrak
Makalah ini membincangkan konflik dan penyelesaiannya dalam Syair Sultan Maulana. Melalui penulisan ini pengkaji ingin membuktikan bahawa karya silam bukanlah lahir daripada kekosongan, tetapi daripada kebijaksanaan pengarang untuk memaknakan maksud yang ingin disampaikan dengan penuh perlambangan. Dalam konteks teks ini pengarang telah mengetengahkan beberapa cara atau kaedah penyelesaian konflik yang digunakan oleh masyarakat silam untuk memastikan keharmonian tanah air terus berlangsung. Oleh itu, makalah ini menggunakan pendekatan penyelesaian konflik yang diperkenalkan oleh Abdullah Hassan dan Ainon Mohd. Melalui pendekatan ini disenaraikan kaedah penyelesaian tersebut seperti berkerjasama, rundingan, dominasi, pengelakan, integriti, obligasi dan kompromi. Karya sastera Melayu terutamanya sastera sejarah tidak pernah lari daripada memuatkan kehidupan masyarakat pada zaman tersebut. Dalam karya sastera tradisional pelbagai isu yang dikemukakan untuk tatapan generasi akan datang. Antara aspek yang sangat menarik untuk dilihat dalam teks klasik termasuklah konflik, masalah atau pertelingkahan yang berlaku dalam masyarakat tersebut sama ada melibatkan golongan diraja, bangsawan mahupun rakyat bawahan.
\end{abstract}

Kata kunci: Konflik, penyelesaian, syair, sastera sejarah, keharmonian

\title{
INTRODUCTION
}

Malay historical literature is a veritable treasure inherited from the Malay forebears. This historical literature often depicts actual events but due to their nature as literary works, they do not contain as much detail as factual historical writings. Yet, they are still able to present events accurately and relevantly. As literary works that reflect ancient cultures, historical texts such as these are recognized as the social documents of bygone societies. This is the view held by Wellek and Warren (1963, p. 102), who stress that "the most common approach to the relations of literature and society is the study of works of literature as social documents, as assumed pictures of social reality". Even though this view dates back to 1963, it is still relevant to the present time. In fact, the view that literature is a reflection of the lives of societies of the past and is a source for understanding the culture and history of the past is also held by Azhar (2017, p. 20), who says, "We can see these narratives as cultural documents that recorded various strands of 
thought in society and can be one of the sources for our understanding of socio-cultural and economic history". Therefore, the view presented by Azhar is in line with that of Wellek and Warren; in other words, the narrative of a literary work is a record or a source by which current generations can understand the culture and history of people from the past.

The transcription of Syair Sultan Maulana by Muhammad Yusoff can be classified as historical literature. This syair (long poem) has 1104 verses and relates about the relationship between Sultan Ahmad Tajuddin Abdul Halim Shah II (known as Sultan Maulana) and the Siamese kingdom. The text also records the war between Burma and Salang, in which Kedah got involved on the orders of Siam. In the course of the analysis of this text, several conflicts are depicted, and these serve to sustain the readers' interest in this narrative. As a historical literary text, this syair was composed for one main reason. This text clearly foregrounds the wisdom of the Malays, especially the Malay kings, in order to resolve conflict without bloodshed. Apart from this, the syair also narrates the superiority of the Malays of Kedah when facing the Burmese upon the instructions of Siam, resulting in Sultan Maulana being awarded the title Chao Phra Ya (Grand Duke) by the King of Siam. However, there is a hidden implication behind this main event concerning the conflict between the Sultan of Kedah and the King of Siam, which almost cost Kedah its sovereignty. This syair also shows the conflict-resolution method applied by Sultan Maulana to resolve any issues faced.

\section{STATEMENT OF THE PROBLEM}

This study was carried out based on several important studies by previous researchers. The researcher encountered several past studies undertaken by scholars of historical texts in the past, such as Hikayat Patani, Hikayat Merong Mahawangsa, Syair Siti Zubaidah Perang China, Misa Melayu, and Syair Perang Mengkasar. However, no studies concerning conflict and conflict resolution in Syair Sultan Maulana were found. Therefore, the main concern of this study is the conflict and conflict resolution found in this text. Apart from focusing on the conflict and resolution as depicted in the text of Syair Sultan Maulana, this study also analyses the actions of the olden-day people to look at how they dealt with problems in a wise and intelligent manner. 


\section{PAST STUDIES}

A number of scholars have undertaken studies in conflict resolution and among them is Siti Hajar Che Man, in her article titled "Memperkenalkan Tatacara Penyelesaian Konflik Tradisional dalam Konteks Kontemporari: Kajian Teks Syair Siti Zubaidah Perang China" ["Introducing Traditional Conflict-Resolution Methods in the Contemporary Context: A Study of Syair Siti Zubaidah Perang China"] (2015). In this article, Siti Hajar not only deals with external but also internal conflict, that is, the unseen conflict between Siti Zubaidah and Sultan Zainal Abidin. In this study, she highlights the woman's superb ability to resolve conflict. Another such study is "Penyelesaian Konflik dalam Misa Melayu" [Conflict Resolution in Misa Melayu] (2015) by Membunga (Siti Meriam Yaacob). Membunga dissects the conflict resulting from the struggle for power and the throne depicted in this text, and lists the methods used by those involved in this conflict. Even the book Rekayasa Kearifan Tempatan dalam Sastera Melayu [Engineering Local Knowledge in Malay Literature] (2014) also contains several articles that deal with conflict resolution, such as "Konflik Resolusi dalam Hikayat Patani" [Conflict Resolution in Hikayat Patani], which was written by Membunga (Siti Meriam Yaacob), Muhammad Haji Salleh, Siti Hajar Che Man, Mohamad Luthfi Abdul Rahman, and Sakinah Abu Bakar. This article discusses the conflict and resolution found in Hikayat Patani. The strength of this article lies in the presentation of each of the conflicts and the strategies used to resolve each of them. This article presents five methods used by the author, that is, domination, obligation, avoidance, deception, and self-defence.

In the same book, Siti Hajar, Muhammad, Mohamad Luthfi, Membunga (Siti Meriam), and Sakinah have conducted an analysis of Sja 'ir Perang Mengkasar [Syair of the Makassar War] entitled "Tatacara Penyelesaian Konflik dalam Sja 'ir Perang Mengkasar" ["Conflict-Resolution Strategies in Sja'ir Perang Mengkasar"]. This syair brings to the fore the clash between East and West. Several conflicts are unearthed by the researchers, that is, conflict of values, power conflict, and economic conflict. These conflicts are more in the form of internal conflicts and are resolved through good values.

Membunga's (Siti Meriam) article titled "Penyelesaian Konflik antara Dua Kuasa dalam Hikayat Merong Mahawangsa" ["Resolution of Conflict Between Two Powers in Hikayat Merong Mahawangsa"] (2019) reveals that Hikayat Merong Mahawangsa is a text that shows how evil will 
never overcome good. The researcher successfully examines not only the conflict between humans and animals, but also between humans and the devil. Membunga stresses that acting wisely is the ideal method for conflict resolution.

A study of Syair Sultan Maulana by Muhammad Yusoff was published by Universiti Malaya in 1980. Apart from transliterating the manuscript, the researcher also deals with the text in five parts: the first part concerns writing and presentation techniques; the second concerns the background of the production of the text; the third concerns the validity of the facts; the fourth chapter discusses the poet; and the final chapter deals with the interpretation of history. This study is important because it led to Muhammad Yusoff's study of Syair Sultan Maulana, though the latter study leans more towards being an analysis of history than literary criticism.

\section{THE CONCEPT AND DEFINITION OF CONFLICT}

Abdullah Hassan and Ainon Mohd (1998, p. 130) state that conflict is something that often occurs in interpersonal relationship and because of the frequency of its occurrence, it should be considered as normal. Every relationship involves individuals who have their own personalities, ideas, emotions, concepts of self, and so forth. Abdullah and Ainon (1998, p. 130) further explain that there are two types of conflict: content conflict, which means that the conflict is centred on a thing, issue, event, or person as the source of the conflict; and relationship conflict, meaning that a relationship exists between the individuals concerned, such as being husband and wife, or children and family members. It could be that the wife opposes the husband, or that the child opposes the parents. Here, the conflict is not due to content but a result of the relationship. Basically, conflict is a failure to agree, or not being able to suit different needs. This means that we do not agree on a certain issue, and we believe that the decision made will not be satisfactory. Conflict basically occurs when there is a clash of priorities, values, objectives, or anything that is different from our own opinion. Conflict can also be defined as a natural phenomenon involving the continued process of perception between two or more people who have different aims, ideas, values, behaviours, or emotions (Md. Yadi, 2006, p.10). 


\section{RESEARCH METHODOLOGY}

The text of Syair Sultan Maulana is examined intrinsically to trace and analyse the elements that exhibit the conflicts occurring in the text. The method employed by the researchers to trace conflict in this text is to study the language aspect of the transliteration of Syair Sultan Maulana by Muhammad Yusoff (1980). Language was the vehicle for authors in the olden days to express their emotions and their wisdom when faced with problems. As such, the present study scrutinizes episodes of conflict by looking at the language aspects (use of metaphor, symbolism, rhetoric, and diction) that reveal the conflict and resolution.

Abdullah (1998, pp. 163-225) suggests eight methods for conflict resolution: negotiation, obligation, domination, avoidance, accusation, deception, weakening the opponent, and cooperation. A combination of methods may also be necessary to achieve agreement because different conflicts require different ways to resolve them. However, for the purposes of this article, only six methods are found to be suitable: negotiation, obligation, domination, avoidance, deception, and cooperation.

\section{TEXT ANALYSIS}

Historical literary texts usually contain elaborations of problems encountered and the lives of the people of the past. This is in line with the view held by Muhammad Haji Salleh (2006, p. 268) that "Malay literature, especially the traditional, was very close to its society. It dealt with its real problems". Since literature by nature has a close relationship to the time in which it is produced, literary works do present real issues. The author narrates each episode creatively, and includes the successes achieved in overcoming each problem; more interestingly, this is done without any bloodshed on home soil in Syair Sultan Maulana.

\section{"Rebelling to Free Oneself"}

The first conflict in this syair occurs when Patani, a state under the protection of Siam, begins to rebel in order to liberate itself from the grasp of Siam. Siam responds by attacking Patani. This event is captured in the lines below:

\section{Kepada Siam berbuat bantahan}

Barang kehendaknya semuanya ditahan 
Sudah diketahui diri kelemahan

Hendak melawan berbunuh-bunuhan

Hendak dilawan Siam berperang

Hal dirinya sekalian kurang

Raja Siam melakukan garang

Dengan sebentar disuruhnya serang

[Against Siam we object

All our wishes they reject

We know our weakness is abject

To fight to the death we do expect

To war against Siam we will go

Although lacking we are so

The King of Siam cruel does show

Swift attack he orders on his foe]

(Syair Sultan Maulana, 1980, pp. 209-210)

As a result, Siam assembles an army at Senggora (Songkhla) to attack Patani. Kedah, which has no interest in this quarrel, is ordered to immediately join the Siamese to attack Patani. They are warned that any delay in doing so will incur the wrath of the Siamese King:

Kedah dan Petani sudah tertentu

Takluk ke benua Siam itu

Tatkala demikian perintah ratu

Kedah pun disuruh memukul ke situ

Angkatan sekalian berhimpun di Senggora

Angkatan Kedah pun suruh sigera

Naik memukul Petani angkara

Jika lambat Kedah pun cedera

[Kedah and Petani, that is sure

To the Siamese king vassals were

The king of Siam sent the order

For Kedah post-haste to go thither 
At Senggora the soldiers did gather

The army of Kedah was to go thither

The Petani rebels to overpower

Without delay, or their kingdom would suffer]

(Syair Sultan Maulana, 1980, p. 210)

The wording of the second line, "Takluk ke benua Siam itu" [to the Siamese king vassals were], and the fourth line, "Kedah pun disuruh memukul ke situ" [For Kedah post-haste to go thither], prove that Kedah, as a vassal state of Siam, has been ordered to destroy Patani.

\section{Conflict Resolution through the Cooperation Method}

In order to resolve conflict and ensure the continued sovereignty of Kedah, Sultan Maulana chooses to cooperate with the Siamese. This proves to be the best strategy for conflict resolution as both sides have long-term goals to protect their own interests (Abdullah \& Ainon, 1998, pp. 203-204). In this context, the Sultan of Kedah wishes to maintain harmony, while the Siamese wish to obtain Kedah's loyalty. As a result of accord between them, Kedah continues to be a trusted ally of Siam. This can be seen in the excerpt of this syair given above: "jika lambat Kedah pun cedera". The word "cedera" (literally: injured) means that should Kedah delay or not assist Siam, it would be attacked by Siam in turn, since Kedah is a vassal of Siam. Therefore, Kedah has no choice but to obey-to refuse would have meant inviting disaster. Kedah is well aware that they were no match for Siam.

\section{Conflict Due to Treason}

However, conflict continues when Datuk Maharaja disobeys the Sultan and refuses to go to war in Patani after hearing that Patani is very powerful and had succeeded in overcoming the Siamese:

Titah tiada juga diberati hingga surat datang berganti maklumkan khabar beribu kati menyatakan Patani terlalu sakti 
Pada Patani sangat diberatkan

keadaan diri tiada diingatkan

kebinasaan negeri tiada disedarkan

khabar yang dusta didengarkan.

[The king's decree lightly was taken

though letter followed letter hard upon

heavy with news again and again

saying that Patani had to be won

Patani was of great importance

Oneself of no consequence

The kingdom almost ruined by ignorance

Untrue report was given credence]

(Syair Sultan Maulana, 1980, p. 213)

The above excerpt of the syair shows how the Kedahan army led by Datuk Maharajalela defied Sultan Maulana because they believed the rumour that the Siamese had been defeated by Patani.

\section{Avoidance Strategy}

The Kedahan army assembles at Padang Terap but delays and does not march to Patani, as Datuk Maharaja attempts to find a way to avoid joining the war, and Paduka Maha Menteri is afraid of going to Patani. Here, Datuk Maharaja and Paduka Maha Menteri use the avoidance strategy to avoid conflict. The avoidance strategy is a strategy that does nothing; it aims to delay or postpone negotiations (Abdullah \& Ainon, 1998, p. 207). This can be seen in the lines from the syair below:

Habis berhimpun segala tentera

di Padang Terap berapakah dura

Maharaja duduk mencari sigera

berlambatan duduk mencari kira

Di Padang Terap sehari-hari

Bermain herabab kecapi, muri

dihimpun menorah disuruh menari

menorah pun mati dengannya sendiri 
[All the soldiers together did come

at Padang Terap, far from their aim

the great king did count on them

but they sought to delay all the same

At Padang Terap every day

The rebab, kecapi and muri they played

with dancers the time they whiled away

the menorah dance till death can they]

(Syair Sultan Maulana, 1980, p. 211)

While at Padang Terap, the Kedahan army does not engage in battle with Patani. Instead, they entertain themselves playing musical instruments, such as the rebab, kecapi and muri, and also with menorah dances. They do not obey the Sultan and merely wait it out on the hope that the rebellion in Patani would soon be over and they would not have to go to war. At the same time, Sultan Maulana is put under pressure by Siam because the Kedahan army has not arrived, while the others are waiting. The Sultan urges his army to proceed with war but to no avail. Although the Sultan's messengers arrive bearing letters and suits of clothing for the officers, he continues to be ignored because they believe the rumour that Patani has defeated Siam. The Patani fortress at Cheni is very strong and impossible for the Kedahan army to defeat:

Sudah berangkat dari Senggora

Duduk berhimpun segala tentera

Di negeri Petani berapakah dura

Angkatan di Kedah tiada ketara

[Senggora they had left long since all assembled were the soldiers in Petani they became nervous nowhere seen were the Kedahan forces]

(Syair Sultan Maulana, 1980, p. 212)

Mudik pergi ke Padang Terap

Membawa persalin cukup semerab

Kurniakan pegawai yang diharap

Itu pun tiada juga mujarab. 
[A messenger to Padang Terap came

Bearing suits of clothing full fine

As gifts for the officers depended upon

Even then nothing was acted upon.]

(Syair Sultan Maulana, 1980, p. 213)

\section{Conflict as a Result of Accusation}

On the insistence of Sultan Maulana, the army proceeds to march on Patani but by this time, the war is over and Patani has been defeated by the Siamese. This incident arouses the anger of the King of Senggora, who chases the Kedahan army back home. However, the Siamese detain the Temenggung (chief of security). The King of Senggora accuses Sultan Maulana of conspiring with Patani and condones Datuk Maharaja's delay tactics, allowing him to remain at Padang Terap and not coming to Siam's aid. So, while in the early stages Datuk Maharajalela successfully employed the avoidance strategy, its success was only temporary. The Kedahan army is punished by the King of Senggora. Avoidance has not brought about a resolution, therefore another strategy becomes necessary to solve the problem. The verses below explain the anger of the Siamese towards Kedah:

Dituduh Siam duli makota
Dengan Datuk hendak beserta
Siam pun hendak berbuat menta
Katanya Kedah hendak diserenta.

Temenggung pun tiada dilepasnya mari

Gundahlah pula seisi negeri

Surat Temenggung berdudun mari

Menyatakan hal berbagai peri.

[The Siamese the king suspected

With the Datuk to have plotted

Siam was infuriated

Kedah to attack they wanted

The Temenggung they did not let go

The entire land was worried so 
Many letters the Temenggung wrote

Telling of all kinds of woes.]

(Syair Sultan Maulana, 1980, p. 217)

\title{
Negotiation Strategy
}

This misunderstanding causes Siam to plan an attack against Kedah. While being detained by the Siamese, the Temenggung writes a letter to Sultan Maulana and tells of the suffering he has to endure during his detention. The Sultan then orders his Laksamana (Admiral) to seek audience with the King of Siam, convey an apology, and obtain the release of captives from Kedah. The Laksamana is ordered to negotiate with the King of Siam. The strategy of negotiation is often used for resolving conflicts. Negotiation also means that the parties involved attempt to force each other to agree with their wants. When one opposes someone's wishes, it is assumed that the source of conflict is a very important matter that must be resolved and that the other party merely wants to win (Abdullah \& Ainon, 1998, pp. 192193). The Laksamana can be deemed as a "peacemaker" between these two opposing sides. In the end, due to the blessing of Sultan Maulana's divine right to rule, the King of Siam forgives Sultan Maulana, and returns all of the gifts as well as the captives, who then return safely to Kedah.

\author{
Dengan kudrat Ilahu'I-ghina \\ Meninggikan daulat Sultan Maulana \\ Tatkala sampai Laksamana \\ Padamlah api yang mengerna. \\ [With the Grace of Allah the needless \\ elevating Sultan Maulana to be peerless \\ when the Laksamana arrived at the place \\ the glowing fire extinguished was.]
}

(Syair Sultan Maulana, 1980, p. 219)

\section{The Strategy of Deception to "Bring Peace to Both Sides"}

The resolution strategy employed by Sultan Maulana proves to be a wise move because he is able to resolve the conflict between himself and the King of Siam without causing any bloodshed in Kedah. More importantly, 
the oratory skills and wisdom of the Laksamana are factors in this conflictresolution strategy in order to bring about peace between these two opposing sides. Without the Laksamana's wisdom and skill, it would surely have been difficult to negotiate with the King of Siam.

\section{Conflict Due to Slander and Blame}

Not long after this, another conflict or misunderstanding occurs between the King of Siam and Kedah. Datuk Maharaja complains to the King of Siam, bad-mouthing Sultan Maulana in the process. At this crucial moment, Burma invades Salang (modern-day Phuket). Being a vassal of Siam, Salang seeks assistance from the King of Siam.

Orang Salang memintok bantu

Segenap negeri bukan suatu

Barang yang takluk ke benua itu

Disuruh sigera pergi ke situ

[The people of Salang begged assistance

Not one or two but all with one voice

Whoever to this kingdom owed allegiance

Was called upon to return at once]

(Syair Sultan Maulana, 1980, p. 221)

The King of Siam comes to Kedah and asks for soldiers and rice to be sent to Salang in order to feed his warring army. The King of Siam also comes to deliver his decree, as well as to warn Sultan Maulana and order him to give Datuk Maharaja the seal and, thus, the reign of Kedah. Sultan Maulana is enraged that the two Datuk Maharaja siblings have slandered him and bad-mouthed him to the King of Senggora:

Datuk Maharaja pegawai bahari

Raja Senggora memanggil mari

cap dipinta pulangkan beri

disuruhnya pulak memerintah negeri.

Sebab demikian kisah ketara

Datuk Maharaja dua bersaudara 
Mengacum kepada Raja Senggora

Memalis malu hendak dikira

[Datuk Maharaja the king's official

By the King of Senggora was recalled hither

the royal seal he asked to be given

to reign the kingdom in his stead.

This tale is one often narrated

Datuk Maharaja and his brother intended

the King of Senggora they influenced

to remove the shame that they suffered]

(Syair Sultan Maulana,1980, p. 225)

\section{The Cooperation Strategy to Repair Relationships}

Before the King of Senggora comes to Kedah, Sultan Maulana receives a letter informing him that Salang is in a state of chaos.

Berbalik pula hendak dicetera

Sebelum datang Raja Senggora

Sepucuk sudah ketara

Menyatakan Salang huru-hara

[But let us then first relate

That before the King of Singgora reached the state

A letter that had arrived of late

Told of tumult in Salang great]

(Syair Sultan Maulana, 1980, p. 226)

The Sultan is extremely saddened that he has no army to send and, at the same time, he fears the recurrence of past events. Kedah finds itself in a precarious position, as this conflict causes tension in the relationship between Siam and Kedah. Therefore, Sultan Maulana endeavours to repair the relationship between the two kingdoms so that peace is maintained. 


\title{
Cooperative Resolution
}

Once again, Sultan Maulana uses the cooperative strategy to help Salang, one of Siam's vassal states, in its war against Burma. In his effort to repair relations with Siam, Sultan Maulana orders his Laksamana to prepare Kedah's forces and equipment for war:

\section{Kepada Laksamana bertitah sultan \\ "Sekarang diri punya jabatan, \\ Segala kerja pihak lautan \\ Dirilah pergi bawa angkatan" \\ [To the Admiral said the sultan \\ "Upon you I bestow this position \\ To deal with all matters of the ocean \\ Take the fleet and leave anon."]}

(Syair Sultan Maulana, 1980, p. 226)

By sending aid to Salang, Sultan Maulana hopes that the tense relationship between Kedah and Siam can be improved and that there will be no more doubt concerning his loyalty on the Siamese side.

\section{Religious Conflict}

In order to mend relations with Siam, Sultan Maulana decides to send his navy under the command of the Laksamana to help fight the Burmese. However, during the course of this war, a new conflict arises. Tunku Idris, a religious scholar fighting on the side of Kedah, is unable to deal with the agony and suffering of war. He issues a religious decree that it is haram (sinful) to aid the Siamese in their war against Burma, because the Siamese are Buddhists:

\author{
Katanya Ugama mereka sebangsa \\ Menyertai diri kita berdosa \\ Baiklah kita balik ke desa \\ menanggung sengsara tiadalah kuasa \\ Wazir tiada menurut bicara \\ Kalau negeri mendapat cedera
}


Sungguhlah ugama tiada setara

Sebab negeri hendak dipelihara.

[It is said they are of one religion thus in joining we commit a sin it is best to our hometowns to return than to bear this suffering.

The Vizier to this did not agree the fatherland would suffer injury of different religions they were certainly yet the fatherland ever protected must be.]

(Syair Sultan Maulana,1980, p. 298)

\section{Domination of Authority: The King's Wishes Must be Obeyed}

Unable to bear the hardship and suffering of the battlefield, Tunku Idris leaves, even though the Laksamana attempts to prevent it. The Temenggung is in agreement with Tunku Idris but turns back because the Sultan decrees that should the Temenggung return to Kedah, he would be put to death. In this situation, Sultan Maulana has used his authority to dominate over the Temenggung by issuing a stern warning that stops the Temenggung from returning to Kedah before the war is over. Domination is also known as a win-lose orientation. Those who dominate try to fulfil their aims without caring about the party over which they dominate. This strategy is used by those who possess authority (Membunga@Siti Meriam et al., 2014; p. 55). In this text, this strategy is used by Sultan Maulana to resolve issues with his subjects. This occurs when the people try to disobey the Sultan's orders. As his subjects, the people are unable to do much, until finally they have no choice but to obey the king's wishes. Sultan Maulana's warnings are reflected in the syair in the following stanzas:

\section{Perintah itu masyur warta sampai ke bawah duli mahkota (baginda) murka jangan dikata sebab hendak memberi leta}

Seorang pegawai dititahkan keluar mari menegahkan 
pulang tiada dibenarkan

jikalau bantah disuruh pinasakan

[The order through the landspread

until it reached the crowned head

(he) beyond words was infuriated

for it was to him an insult great.

An officer with this decree was sent

to leave no one was permitted

to return home was prohibited

and death to any who disobeyed.]

(Syair Sultan Maulana, 1980, pp. 299-300)

\section{Strategies: Obligation and Cooperation}

The above strategies are evident when the Temenggung is warned that he would be put to death should he return to Kedah. This action is taken to ensure that Kedah is safe from Siamese attack. At the same time, this punishment is a warning or threat to any Kedahan soldier who attempts to leave the battlefield. Sultan Maulana issues this decree because he does not want what has happened previously during the Patani revolt to happen again. In actuality, the war between Siam and Burma is not in any way of interest to Kedah but, as a vassal state of Siam, the latter is forced to become involved. Sultan Maulana realizes that it is senseless to aid Siam in its war against Burma, but for the sake of Kedah's sovereignty, he is forced to comply. Were Kedah to refuse, Siam would surely see this as an act of treachery and attack Kedah. Sultan Maulana, recognizing that Kedah is incapable of winning a war against Siam, wishes to avoid this unwanted situation. To keep Kedah safe, the Sultan has no choice but to acquiesce to the demands of the King of Siam. This is a good strategy by Sultan Maulana because, in the end, it is Kedah's assistance to Salang in defeating Burma for which the King of Siam gives recognition and reward. This is seen in the following three stanzas of the syair:

Siam pun sangat memuji-muji

Pekerjaan Melayu bagai disuji

tiada suatu dilihat yang keji

laksana emas sudah teruji. 
Perintah wazir semua kelihatan tiada dilihat suatu kejahatan dengan sebenar segala perbuatan hilanglah segala fitnah dan hasutan

\author{
Pekerjaan baginda tiadalah cela \\ dikerja oleh wazir yang 'ali ('ala) \\ menjadi kebajikan kerja segala \\ kepada Siam terpuji pula \\ [Siam heaped much praise upon \\ the Malays whose actions flaws had none \\ it seemed that they could do no wrong \\ alike to gold whose worth was proven \\ The order of the vizier to all was plain \\ nothing bad in it was seen \\ with the sincerity of all action \\ gone was all slander and instigation \\ His Majesty's doings unaffected \\ by the whatever the high vizier did \\ only all good was seen in it \\ full of praise was Siam over it]
}

Based on each episode of the conflict as presented by the author of Syair Sultan Maulana, it can be seen that the poet manages to compose a narrative that is full of unique qualities by presenting each conflict and the corresponding strategy for its resolution. Therefore, each of the six strategies presented by the author of Syair Sultan Maulana, namely negotiation, obligation, domination, avoidance, deception, and cooperation, is extremely suitable in order to resolve the conflict that takes place.

Therefore, through the resolutions that are shown to have been achieved between the parties in conflict in this text-Kedah and Siam - it can be seen that literary works are important social documents applicable for society, both in the past and in the present time, and continue to be discussed. They prove that old literary works never become antiquated where discussion of issues is concerned, and can be used as references by the current generation. 
Apart from this, the kind of conflict resolution presented in this syair refutes the opinions of Western scholars, such as Wilkinson (in Sweeney, 1980, p.1) and J.C Bottom (in Maier, 1985, p. 16) that Malay literary works are full of fairy tales and empty harbour side lore.

\section{CONCLUSION}

The conflict in Syair Sultan Maulana involves two parties who are both influential, as well as between subordinates and figures of authoritybetween two rulers, and between ruler and subject. The ability of a ruler to find a resolution without causing bloodshed is his wisdom. The wisdom of a sultan is usually linked to his divine right to rule.

The Malays of the past were convinced of the invincibility of rulers, whom they revered due to their divine right to rule (daulat) and which they linked to the king's success in solving problems. This further increased their reverence for the king and indirectly increased their level of loyalty to the king or ruler. Syair Sultan Maulana highlights loyalty that involves no other priority besides maintaining the sovereignty over the kingdom and avoiding destruction by the Siamese.

This syair displays many ways in which problems faced are wisely solved. Although the methods used are captured in a literary text, the idea or knowledge is still transmitted to the current generation, so that they may resolve problems wisely if they encounter any. In this text, the author successfully narrates the episodes of conflict that take place and their respective solution in a very dramatic way using well-worded expressions.

\section{REFERENCES}

Abdullah Hassan and Ainon Mohd. (1998). Berkonflik dan Berunding. Kuala Lumpur: Utusan Printcorp Sdn. Bhd.

Azhar Ibrahim (2017). Historical Imagination and Cultural Responses to Colonialism and Nationalism. Selangor: Strategic Information and Research Development Centre.

Maier, H.M.J. (1985). Fragments of Reading. Alblasserdam: Kanters.

Md. Yadi Said. (2006). Mengurus Konflik. Kuala Lumpur: PTS.

Membunga@Siti Meriam Yaacob (2015). "Penyelesaian Konflik dalam Misa Melayu" in Kearifan Tempatan: Pandainya Melayu dalam Karya Sastera. Rahimah A. Hamid (ed.). Pulau Pinang: Universiti Sains Malaysia. 
Membunga@Siti Meriam Yaacob, Muhammad Haji Salleh, Siti Hajar Che Man, Mohamad Luthfi Abdul Rahman and Sakinah Abu Bakar (2014). Konflik Resolusi dalam Hikayat Patani. Rahimah A. Hamid, Saad Othman and Ahmad Moghni Salbani (Eds.), Rekayasa Kearifan Tempatan dalam Sastera Melayu. Pulau Pinang: Universiti Sains Malaysia.

Membunga@Siti Meriam Yaacob. (2019). Penyelesaian konflik antara Dua Kuasa dalam Hikayat Merong Mahawangsa. Siti Hajar Che Man (Ed.), Penyelesaian Konflik dalam Kesusasteraan Melayu. Pulau Pinang: Universiti Sains Malaysia.

Muhammad Haji Salleh. (2006). Romance and Laughter in The Archipelago: Essays on Classical and Contemporary Poetics of the Malay World. Pulau Pinang: Universiti Sains Malaysia.

Muhammad Yusoff Hashim. (1980). Syair Sultan Maulana: Suatu Kajian Kritis tentang Hasil Pensejarahan Melayu Tradisional. Kuala Lumpur: Universiti Malaya.

Siti Hajar Che Man (2015). Memperkenalkan Tatacara Penyelesaian Konflik Tradisional dalam Konteks Kontemporari: Kajian Teks Syair Siti Zubaidah Perang China. Rahimah A. Hamid (Ed), Kearifan Tempatan: Pandainya Melayu dalam Karya Sastera. Pulau Pinang: Universiti Sains Malaysia.

Siti Hajar Che Man, Muhammad Haji Salleh, Mohamad Luthfi Abdul Rahman, Membunga@Siti Meriam Yaacob and Sakinah Abu Bakar (2015).Tatacara Penyelesaian Konflik dalam Sja'ir Perang Mengkasar. Rahimah A. Hamid, Saad Othman and Ahmad Moghni Salbani (Eds.), Rekayasa Kearifan Tempatan dalam Sastera Melayu. Pulau Pinang: Universiti Sains Malaysia. Sweeney, Amin (1980). Authors and Audiences in Traditional Malay Society. Berkeley: University of California.

Wellek, Rene and Warren, Austin. (1963). The Theory of Literature. Middlesex: Penguin Books.

Received: 4 August 2019

Accepted: 14 November 2019 